E3S Web of Conferences 1, 34003 (2013)

DOI: $10.1051 / \mathrm{e} 3$ sconf/20130134003

(C) Owned by the authors, published by EDP Sciences, 2013

\title{
Determination of selected toxic elements in leaves of White Hawthorn grown in a remote area
}

\author{
M. Zeiner ${ }^{1}$, I. Juranović Cindrić ${ }^{2}$, D. Mihajlov Konanov ${ }^{3}$ and G. Stingeder ${ }^{4}$ \\ ${ }^{1}$ Division of Analytical Chemistry, Department of Chemistry, University of Natural Resources and Life Sciences, 1190 \\ Vienna, AUSTRIA, michaela.zeiner@boku.ac.at \\ ${ }^{2}$ Laboratory of Analytical Chemistry, Department of Chemistry, Faculty of Science, University of Zagreb, 10000 \\ Zagreb, CROATIA, iva.juranovic-cindric@chem.pmf.hr \\ ${ }^{3}$ Laboratory of Analytical Chemistry, Department of Chemistry, Faculty of Science, University of Zagreb, 10000 \\ Zagreb, CROATIA, darija1512@gmail.com \\ ${ }^{4}$ Division of Analytical Chemistry, Department of Chemistry, University of Natural Resources and Life Sciences, 1190 \\ Vienna, AUSTRIA, gerhard.stingeder@boku.ac.at
}

\begin{abstract}
One important plant of the Rosaceae family which is commonly used as phytopharmaceutical in Europe and North America is Hawthorn (Crataegus monogyna). The fruits, the leaves together with their extracts are applied in patients suffering mild cardiac disorders or nervosity. Since the leaves as well as the berries act as diuretics a sufficient micronutrient supply has to be guaranteed. On the other the quantities of toxic elements present in the plant parts should be at levels without harmful effects on human health. For this purpose Hawthorn leaves and flowers were collected in a remote area in 2011 and 2012 and analysed for their elemental composition. The metals uptaken from the soil were supposed to be in a similar range, thus the impact of airborne contamination by heavy metal translocation could be studied. The elements investigated were $\mathrm{Ba}, \mathrm{Cd}, \mathrm{Co}, \mathrm{Cr}, \mathrm{Cu}, \mathrm{Mn}, \mathrm{Ni}, \mathrm{Pb}, \mathrm{Sr}$, and $\mathrm{Zn}$. After harvesting the samples were dried, homogenized, digested and then analysed by ICP-AES. The contents of all elements are in the $\mu \mathrm{g} / \mathrm{g}$ range. In the samples of 2012 higher concentrations were found for $\mathrm{Co}, \mathrm{Cu}, \mathrm{Mn}, \mathrm{Ni}$, and $\mathrm{Zn}$, lower concentrations were registered for $\mathrm{Ba}, \mathrm{Pb}$, and $\mathrm{Sr}$. The amounts of $\mathrm{Cd}$ and $\mathrm{Cr}$ were statistically insignificantly lower in 2012 than 2011.
\end{abstract}

Key words: Heavy metals, White Hawthorn, ICP-AES, airborne contamination

\section{Introduction}

Although metals are long known elements, their role in biological and environmental systems has not been studied for long. The possibility of studying more accurately their dose and effects in more recent times promoted metal related investigations. The investigation of toxic metals and those which cause environmental pollution started during the 1950s and 1960s. (Adriano, 2001) The dissemination of metals into the environment from industrial activities ensures that a significant part of the population is exposed to these contaminants. Vegetation represents a useful indicator of heavy metal contamination in environment not only via root uptake of metals, but also via precipitation from air, thus it can be used for monitoring pollution across both spatial and temporal scales. Whereas the composition of the mother rock does not change over time, the elemental soil composition depends from impact by contamination. Not only on-site, but even in remote areas, metal contamination can be found due to translocation processes.

Hawthorn (Crataegus monogyna), a member of to the Rosaceae family, is one commonly used phytopharmaceutical in European and North American. Hawthorn is a perennial plant growing in moderate, continental climate in the northern hemisphere in deciduous forests and underbrush. It is applied against mild cardiovascular diseases such as congestive heart failure, high blood pressure, hypoxia and hyperlipemia or nervosity (Baughman and Bradley 2003; Holubarsch et al. 2008). For therapeutic purposes mainly berries, flowers and leaves collected in spring time are used. The compounds of pharmaceutical relevance are present in the plant mainly in spring. The absence of these substances in autumn could influence the amount of metals uptaken and accumulated. Furthermore, even if the trees used for harvesting grow in a remote area non negligible quantities of toxic elements may be found in different parts of the plant, in dependency of the 
collection time.

Thus, to study these parameters leaves of White Hawthorn were harvested at the same place in autumn 2011 and spring 2012 and analysed for their content of $\mathrm{Ba}, \mathrm{Cd}, \mathrm{Co}, \mathrm{Cr}, \mathrm{Cu}, \mathrm{Mn}, \mathrm{Ni}, \mathrm{Pb}, \mathrm{Sr}$, and $\mathrm{Zn}$. In addition this study should be provide data for a general elemental characterisation of White Hawthorn leaves, since this plant has been mainly analysed for its organic composition responsible for the antioxidant and antimicrobial activities (Kostic et al. 2012).

\section{Materials and Methods}

\section{Chemicals}

For the experimental work $\mathrm{HNO}_{3}$ (p.a.) and a multi-element standard (ICP Multi-element Standard IV, Merck, Darmstadt, FRG) were used. All glassware was cleaned with nitric acid prior to use. Ultrapure water produced in-house was used for all dilutions and blanks.

\section{Samples and sample preparation}

All samples (White Hawthorn leaves) were collected from Hawthorn trees growing in Slunj, Croatia (N 45,07 - E 15,36 ${ }^{\circ}$; A $280 \mathrm{~m}$ ) in September 2011 and April 2012. Prior to use they were stored in a dry, dark and cool room. The samples were then dried and homogenised in a metal free mortar.

The resulting powder of the leaves (approx. $0.2 \mathrm{~g}$ ) was digested with 50:50\% v/v $\mathrm{HNO}_{3}$ and $30 \% \mathrm{H}_{2} \mathrm{O}_{2}$ in a MWS-2 Microwave System Speedware BERGHOF applying a three step procedure $\left(110^{\circ} \mathrm{C} / 15 \mathrm{~min}\right.$ $\left.170^{\circ} \mathrm{C} / 15 \mathrm{~min}-140^{\circ} \mathrm{C} / 15 \mathrm{~min}\right)$. The clear digest solutions

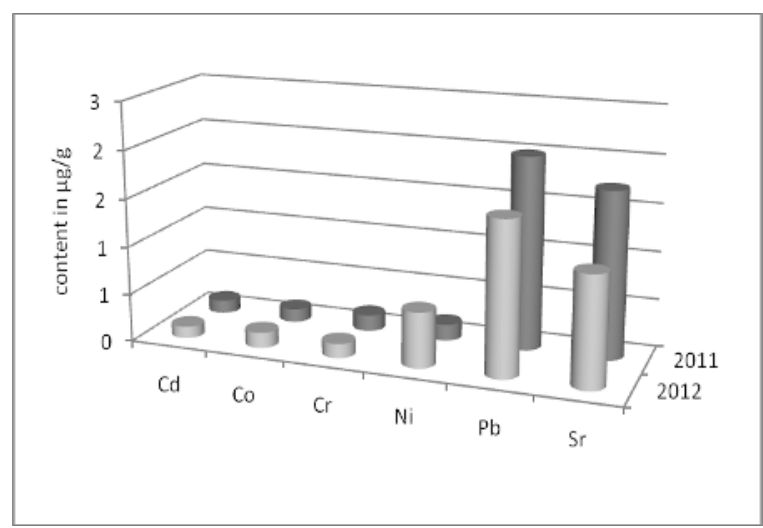

\section{Comparison with other leaves}

Due to the lack of metal concentrations for Hawthorn leaves in literature the results reported on leaves from other trees were used for comparison. A study of poplar leaves (Portugal) obtained values of 2 to $3 \mu \mathrm{g} / \mathrm{g}$ for $\mathrm{Pb}, 0.1$ to $0.2 \mu \mathrm{g} / \mathrm{g}$ for $\mathrm{Cd}$, and 4 to $5 \mu \mathrm{g} / \mathrm{g}$ for $\mathrm{Cu}$ (Silva et al. 2005). These results are in the same order of magnitude as those of the presented study, namely 1.5 to $2 \mu \mathrm{g} / \mathrm{g}, 0.12$ to $0.14 \mu \mathrm{g} / \mathrm{g}$, and 6 to $7.5 \mu \mathrm{g} / \mathrm{g}$ for $\mathrm{Pb}, \mathrm{Cd}$, and $\mathrm{Cu}$, respectively. Similar concentrations were also found in peppermint leaves used for preparation of were filled up to $10 \mathrm{~mL}$ with ultrapure water.

\section{Measurements}

The ICP-AES determinations of the mineral content of the Hawthorn leaves were performed using a Prodigy High Dispersive ICP-AES spectrometer (Teledyne Leeman, Hudson, NH, USA) working in a simultaneous mode, equipped with a glass concentric nebuliser. All measurements were run in triplicate.

\section{Results and Discussion}

\section{Analytical figures of merit}

The precision of the method expressed in RSD ranged from 0.6 to $5 \%$, the accuracy evaluated by determining the recoveries of the analytes by spiking experiments are from $84-115 \%$.

\section{Metals in White Hawthorn leaves}

The metal determination of the White Hawthorn leaves showed that all elements could be detected. They were all found in quantities of $\mu \mathrm{g} / \mathrm{g}$ dried matter (see fig. 1). Differences determined by collection time can be seen for all elements. In order to check the statistically significance of the differences a paired t-test was performed with all data sets. This revealed statistically significant differences for all metals studied except for $\mathrm{Cd}$ and $\mathrm{Cr}$. In the samples of spring 2012 higher concentrations were found for $\mathrm{Co}, \mathrm{Cu}, \mathrm{Mn}, \mathrm{Ni}$, and $\mathrm{Zn}$, whereas lower concentrations were registered for $\mathrm{Ba}, \mathrm{Pb}$, and $\mathrm{Sr}$ than in those from autumn 2012.

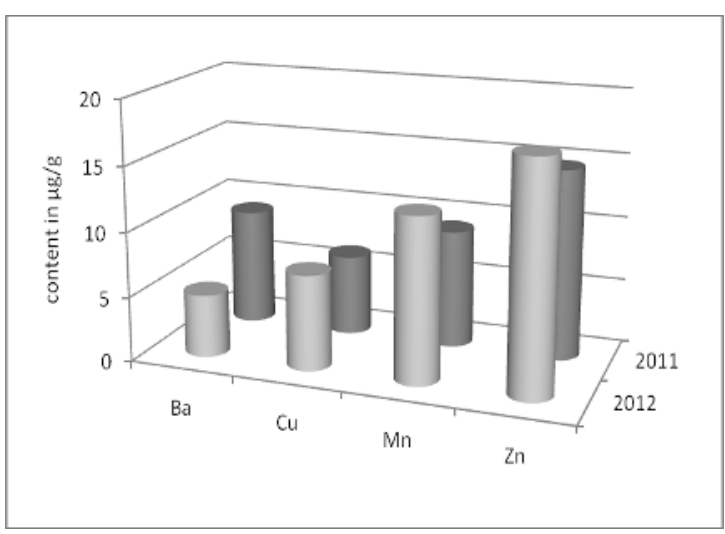

Fig. 1. Content of $\mathrm{Ba}, \mathrm{Cd}, \mathrm{Co}, \mathrm{Cr}, \mathrm{Cu}, \mathrm{Mn}, \mathrm{Ni}, \mathrm{Pb}, \mathrm{Sr}$, and $\mathrm{Zn}$ in White Hawthorn leaves collected in 2011 and 2012.

infusions (Polish tea bags): for $\mathrm{Pb}, \mathrm{Cd}$, and $\mathrm{Cu} 2.41 \mu \mathrm{g} / \mathrm{g}$, $0.09 \mu \mathrm{g} / \mathrm{g}$, and $12 \mu \mathrm{g} / \mathrm{g}$, resp. (Lozak et al. 2002). In general mint leaves contain higher amount of metals than White Hawthorn leaves as can be seen in table 1 .

Table 1: Seleceted elements in leaves from White Hawthorn (WH) and mint (M; Lozak et al. 2002)

\begin{tabular}{|c|c|c|}
\hline Element & $\mathrm{WH}[\mu \mathrm{g} / \mathrm{g}]$ & $\mathrm{M}[\mu \mathrm{g} / \mathrm{g}]$ \\
\hline $\mathrm{Ba}$ & $4.8-9.0$ & 31.2 \\
\hline $\mathrm{Co}$ & $0.13-0.16$ & 0.10 \\
\hline
\end{tabular}




\begin{tabular}{|c|c|c|}
\hline $\mathrm{Cr}$ & $0.15-0.17$ & 0.94 \\
\hline $\mathrm{Mn}$ & $9.0-13$ & 188 \\
\hline $\mathrm{Ni}$ & $0.17-0.57$ & 2.99 \\
\hline $\mathrm{Sr}$ & $1.2-1.7$ & 2.40 \\
\hline $\mathrm{Zn}$ & $15-18$ & 51.0 \\
\hline
\end{tabular}

\section{Comparison with Hawthorn fruits}

A Turkish research group (Özcan et al. 2005) analysed Hawthorn frutis for their physical and chemical properties. $\mathrm{Cr}, \mathrm{Ni}$, and $\mathrm{Pb}$ were found in the fruits in amount of about $1 \mu \mathrm{g} / \mathrm{g}$.

\section{Conclusion}

Parts of perennial trees growing in remote areas present good samples for investigating environmental contamination and translocation processes. In this pilot study statistically significant differences in the elemental composition of White Hawthorn leaves collected in autumn 2011 and spring 2012 could be found for $\mathrm{Co}, \mathrm{Cu}$, $\mathrm{Mn}, \mathrm{Ni}$, and $\mathrm{Zn}$ (increase), and for $\mathrm{Ba}, \mathrm{Pb}$, and $\mathrm{Sr}$ (decrease). No statistically significant changes were registered for $\mathrm{Cd}$ and $\mathrm{Cr}$. These differences may be caused by variations in the weather situation (amount of precipitation) and translocation processes. On the other hand the composition regarding organic compounds of pharmaceutical relevance changes from autumn to spring. Only the fresh plant parts contain the required concentration of phenolic compounds, flavonoids and anthocyanins.

Further research will be focused on longer time periods to be studied ( 5 - 10 years), trees from different areas and a correlation between elemental composition and amounts pharmaceutical active substances.

\section{References}

Adriano DC. Trace elements in terrestrial environments: biogeochemistry, bioavailability, and risks of metals. Springer, New York 2001 ( $2^{\text {nd }}$ ed.)

Baughman KL, Bradley DJ. Hawthorn Extract: Is It Time to Turn Over a New Leaf? Am J Med 2003; 114:700-701.

Holubarsch CJF, Colucci WS, Meinertz T, Gaus W, Tendera M. The efficacy and safety of Crataegus extract WS ${ }^{\circledR} 1442$ in patients with heart failure: The SPICE trial. Eur J Heart Fail 2008; 10:1255-1263.

Kostic DA, Velickovic JM, Mitic SS, Mitic MN, Randelovic SS. Phenolic Content, and Antioxidant and Antimicrobial Activities of Crataegus Oxyacantha L (Rosaceae) Fruit Extract from Southeast Serbia. Trop J Pharm Res 2012; 11:117-124.

Lozak A, Soltyk K, Ostapczuk P, Fijalek Z. Determination of selected trace elements in herbs and their infusions. Sci Tot Environ 2002, 289:33-40.

Özcan M, Hacseferogullar H, Marakoglu T, Arsaln D. Hawthorn (Crataegus spp.) fruit: some physical and chemical properties. J Food Eng 2005, 69:409-413.

Silva NAF, Lopes MI, Leitao RAE, Silva HFA, Matos MJ. Simultaneous Monitoring of Toxic Metals on White Poplar (Populus) by SWASV. J Braz Chem Soc 2005, 16:1275-1282. 